\title{
セル体の振動貫入に関する研究
}

\section{A STUDY OF CELLULAR SHELL DRIVING INTO GROUND USING VIBRATION HAMMERS}

\author{
高 井 俊 郎* · 今野建太郎** · 荻 野秀 雄*** - 中 村 正 邦**** \\ By Toshiro TAKAI, Kentaro IMANO, Hideo OGINO and Masakuni NAKAMURA
}

\begin{abstract}
Embedded Steel Plate Cell Method were used in the construction of a 1790 meter sec tion of the seawall for the Kansai International Airport Island. The steel cells were driven into soil improved by Sand Compaction Pile Method using synchronized vibration hammers and water jets.

Based on the data obtained during actual driving operations, the mechanism of vibration driving and the effect of water-jetting were studied in relation to the dynamic and hydraulic behavior of the soil in order to determine the optimum combination of vibration hammers and water jets for various all parameters and soil conditions.

The results of this study can be applied to the planning of a variety of cell and pile driving situations.

Keywords: embedded steel plate cell, vibration driving, water jet, synchronized vibration hammers, sand compaction pile
\end{abstract}

\section{1. まえがき}

根入れ式鋼板セル工法は 1979 年に実用化された工法 で，あらかじめ加工した鋼板セルを同調運転させた数台 のバイブロハンマーによって一気に海底地盤に打ち込 み, 中詰めを行った後セル間をアークで接続して護岸や 岸壁を築造する工法である。この工法の施工実績はまだ 少ないが, 関西国際空港の空港島建設では外周護岸約 $11 \mathrm{~km}$ のうち護岸延長 $1790 \mathrm{~m}$ にわたって採用された。

当護岸においてはバイブロハンマーにウォーター ジェットを併用してセルの打設を行った. バイブロハン マーによる振動杭打ち工法やジェット併用工法は 1950

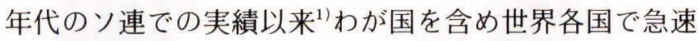
に普及してきたが，バイブロハンマーの施工仕様や ジェット併用時の仕様の決定に際しては, 依然として従 来の施工実績に基づいた経験則を主体にしているのが実 情であり, 理論的研究はほとんどなされていない。

* 正会員 工修 関西国際空港 (株) 建設事務所所長 ( ₹596 岸和田市大北町 9-25)

** 正会員 東亜建設工業 (株) 大阪支店関西国際空港室 ( ₹550 大阪市西区勒本町 1-5-15)

*** 正会員 東亜建設工業 (株) 技術開発部 （广102 千代田区四番町 5)

***** 正会員 不動建設 (株) 特殊工法事業本部 ( ₹110 台東区台東 1-2-1)
本論文では，関西国際空港の空港島建設における根入 れ式鋼板セル護岸の施工概要を述べたあと，バイブロハ ンマーによる振動貫入に対して振動諸元および地盤条件 を用いたバイブロハンマーの出力算定式を提案し，同時 にジェット併用時のバイブロハンマー出力の低減率算定 式を導いた。さらに現場の施工記録をもとにセルの振動 貫入特性やジェットの低減効果を調ベ，上記算定式と実 測値との対比を行い，算定式の有効性を確かめた.

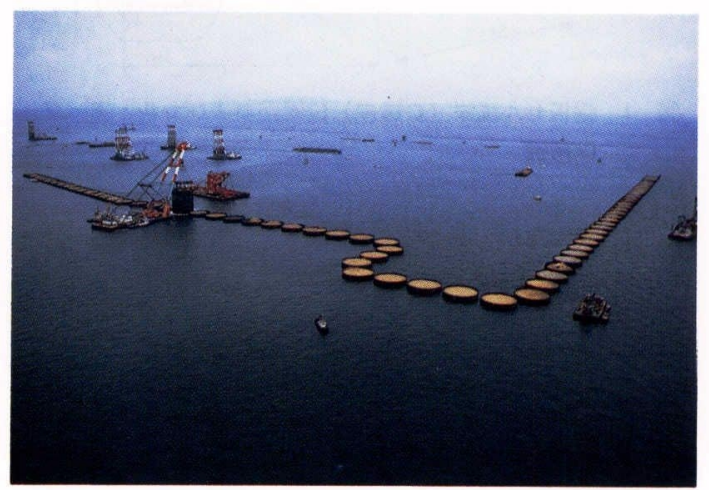

写真一1 根入れ式鋼板セル護岸施工全景 


\section{2. 根入れ式鋼板セル護岸の施工概要}

関西国際空港の空港島建設における根入れ式鋼板セル 護岸は，図一1 に示すように北東部の連絡橋取付部を中 心とする $1790 \mathrm{~m}$ であり, 過去の施工実績と比べて, セ ルの大きさ・施工延長とも最大規模である．また本工事 としては初めてウォータージェットが補助工法として用 いられた。

\section{(1) 施工概 要}

護岸の施工順序および標準断面図を図一2に示す。水 深 16.5 19.0 $\mathrm{m}$ の海底地盤上に厚さ $3 \mathrm{~m}$ (海砂約 $1 \mathrm{~m}$ の上に山砂約 $2 \mathrm{~m}$ ) の敷砂を敷設したあと, 層厚 16〜 $20 \mathrm{~m}$ の沖積粘土層全層にわたってサンドコンパクショ ンパイル $(\mathrm{SCP})$ 工法により改良率 70 \% (砂杭直径 $2.0 \mathrm{~m}$ ，ピッチロ $2.1 \mathrm{~m})$ の地盤改良を実施した.ここ では SCP 打設に伴う隆起地盤についても原地盤と同じ 仕様で改良し，隆起土の有効利用が図られた。

このような SCP 改良地盤中に別途製作されたセル全 69 函を所定深さー $19.0 \mathrm{~m}$ まで打設し，ただちに山砂に よる中詰めを行った.引続きアーク全 136 枚をセルの ジョイント部に打設し, 同様に中詰めを行った.

\section{（2）改良地盤の特性}

原地盤は平均一軸圧縮強さ $q_{u}=0.04 z\left(\mathrm{kgf} / \mathrm{cm}^{2}\right)(z$

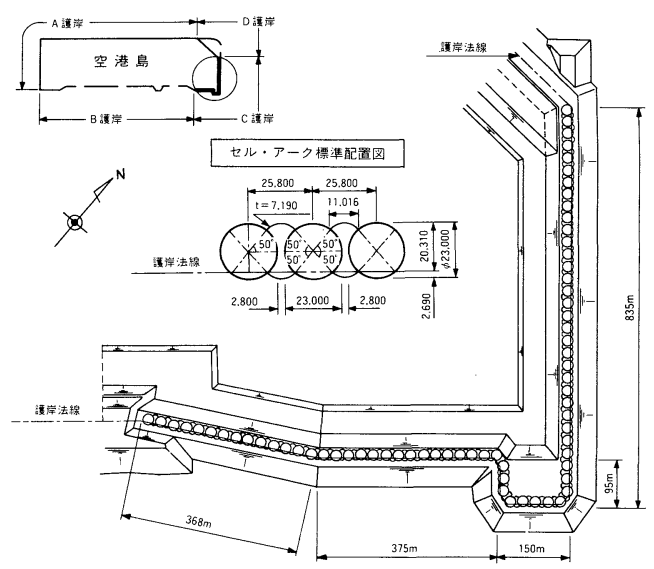

図一1鋼板セル護岸（C 護岸）位置図およびセル・アーク 配置図

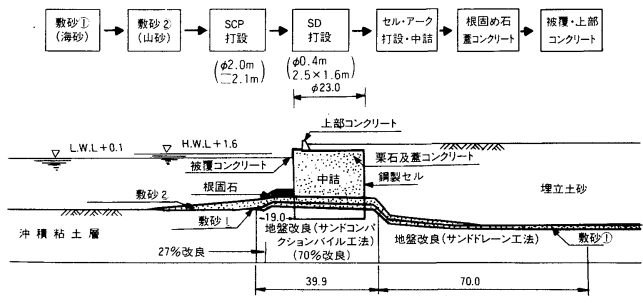

図一2 鋼板セル護岸（C護岸）標準断面図
: 海底面からの深さ， $\mathrm{m})^{3)}$ の沖積粘土層であるが，七 ル打設時の地盤はSCP 工法で強制置換された改良地盤 である. 図一3 は砂杭のチェックボーリング結果のうち セルの根入れ部分に担当する上部 $11 \mathrm{~m}$ の $N$ 值分布を示 したものである. 改良地盤はおおむね深さ $z$ 方向に増 加傾向を示し, $N$ 値 $=1 \cdot z \sim 5 \cdot z$ の範囲で分布している が，ばらつきの原因としては杭間粘性土や敷砂（山砂） 中の大粒径岩砕の影響などが考えられる，分布傾向をみ ると $N$ 値 $=2 \cdot z \sim 3 \cdot z$ の間に全デー夕の約半分が集中し ており, 平均 $N$ 値 $=2.5 z$ 程度の砂質地盤と考えられる. $\mathrm{SCP}$ による護岸部の平均隆起高さは $4.8 \mathrm{~m}$ であり, 従 来の予測手法による予測隆起高さ $2.8 \mathrm{~m}$ を大きく越え ている2),3).

\section{（3）セルの打設}

セルの打設装置は 8 台のバイブロハンマーが同調運転 できるようにしたもので，その打設能力は護岸設計時の 想定 $N$ 値（敷砂層 5 ，隆起地盤 10 ，原地盤 15）をもと に施工・積算マニュアルによる算定法および過去の施工 実績を検討のうえ決定された. しかしセル打設が開始さ れたのち, SCP 改良地盤が想定 $N$ 值を上回り，そのう え隆起高さが当初の予測值を大きく越え根入れ長の増大 につながったことなどが原因で所定深さへの打設が困難 となったため，その対策としてバイブロハンマ一台数は そのままとし, ジェットをセル打設 4 函目から補助工法 として併用することとした. ジェットは污濁が拡散しな いようにセル内側にジェット配管がなされ，ジェットノ ズル（口径 $4.5 \mathrm{~mm}$ ) がセル下端より $20 \mathrm{~cm}$ 上方に約 $1.5 \mathrm{~m}$ 間隔で計 48 か所取り付けられた。 セルの打設装 置を図一4, 表一1 に示す. またバイブロハンマーおよび ジェットなどセル打設能力に関する諸元を表一2に示

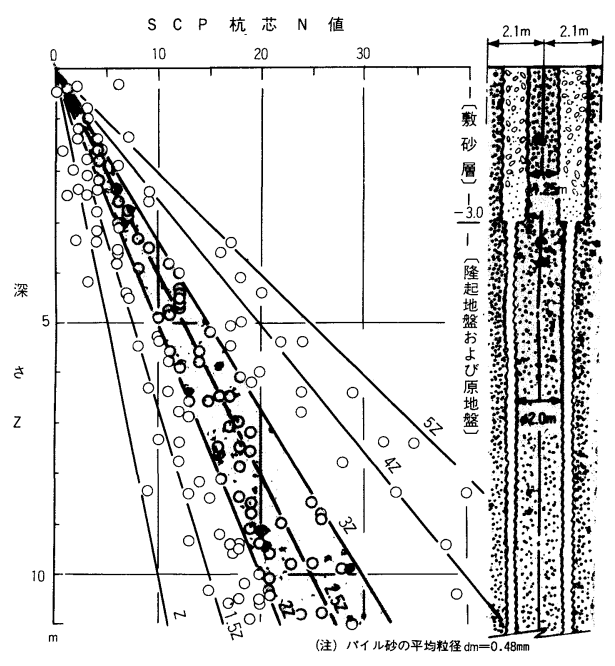

図一3 SCP 改良地盤チェックボーリング結果 


\section{表一1 打設装置の主要構成}

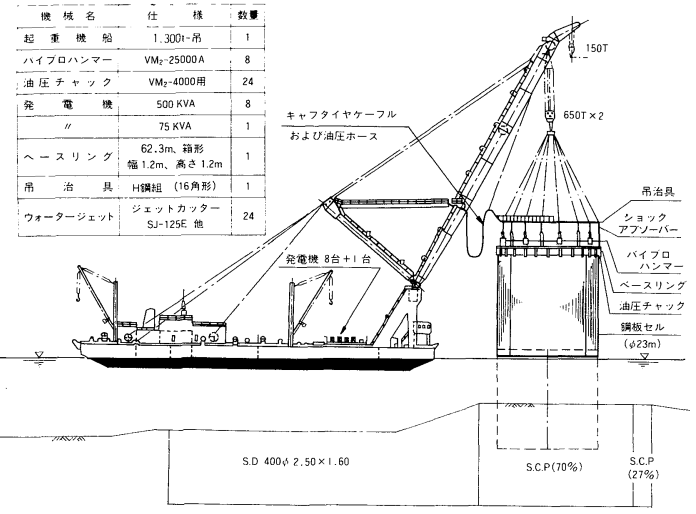

図一4 セル本体打設装置姿図

表一2 セル・アーク関係主要諸元

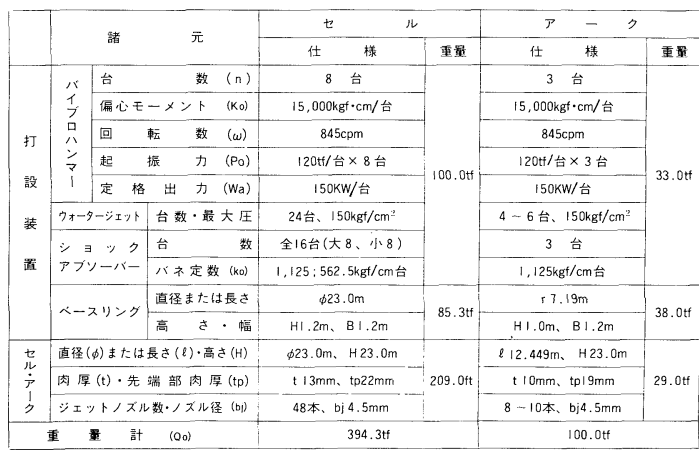

$\Phi^{4)}$.

セル打設中は, セルの位置, 傾斜, 打設深さ, 貫入速 度，バイブロハンマー出力などを計測管理しながら ジェット圧力を適宜増減させた。またセルの打止め管理 は打設完了直前にジェットを停止し，バイブロハンマー のみによって周辺地盤の締固めを数分間行った.

アークの打設については，七ルの継手にアーク継手を はめ込んで建て込み，七ルと同様バイブロハンマーと ジェットの併用によって打設した。 セル，アークの打設 深さは隆起高さによって異なり 8〜 $13 \mathrm{~m}$ ，打設水深は 6 〜11 mであった.

\section{3. バイブロハンマーによる振動貫入の理論的 検討}

振動杭打ち工法や根入れ式鋼板セル工法について述べ た文献は工事報告を中心として数多くあるが，振動貫入 機構に関するものはごくまれである．本章ではまず既往 の知見について述べたあと，バイブロハンマーによる振 動貫入に対し理論的検討を行い，新たにバイブロハン マー出力式を導く.

\section{（1） 既往の知見}

バイブロハンマーによるセルの貫入能力については施 工積算マニュアル 海象条件, 土質条件, 工期・工費などを考慮し, 適切な 能力を算定して行う」とされており，バイブロハンマー 使用台数決定のために以下の検討式が示されている.

$$
\begin{aligned}
& a_{0} \geqq a^{\prime}, \quad P_{0}>R_{f}, \quad Q_{0}>R_{p} \cdots \cdots \ldots \ldots . . . \\
& R_{f}=\mu\left(N / 5 \cdot l_{s}+c \cdot l_{c}\right) \cdot 2 \pi D \\
& \mu=0.05+0.95 \exp \left(-0.77 \eta_{0}\right) \text { 砂質土 } \\
& \quad=0.13+0.87 \exp \left(-0.77 \eta_{0}\right) \text { 粘性土 } \\
& \eta_{0}=P_{0} / Q_{0}, \quad P_{0}=n \cdot p_{0} \\
& R_{p}=10 \alpha N A_{p} \exp \left(-2.06 I^{1 / 2}\right) \cdots \cdots \cdots \cdots
\end{aligned}
$$

ここに, $n$ : バイブロハンマー台数, $P_{0}$ : バイブロハン マ一の総起振力 $(\mathrm{tf}), p_{0}$ : 同 1 台当たり起振力 $(\mathrm{tf})$, $Q$ : 総振動重量 $(\mathrm{tf}), a_{0}$ : バイブロハンマーの初期振幅 $(\mathrm{m}), a^{\prime}$ : 必要振幅 $(=0.003 \mathrm{~m}), R_{f}$ : 振動時の周面 摩擦 $(\mathrm{tf}), R_{p}$ : 振動時の先端抵抗 $(\mathrm{tf}), \mu$ : 振動時の 周面摩擦低減率, $N$ : 砂質土の $N$ 值, $c$ : 粘性土の粘 着力 $\left(\mathrm{tf} / \mathrm{m}^{2}\right), l_{s}, l_{c}$ : 砂質土, 粘性土それぞれの根入れ 長 $(\mathrm{m}), D$ : 七ル直径 $(\mathrm{m}), A_{p}$ : 七ルの先端面積 $\left(\mathrm{m}^{2}\right)$, $I$ : バイブロハンマーの力積 $(\mathrm{tf} \cdot \mathrm{s}), \eta_{0}$ : セルの初期振 動加速度 $(\mathrm{G}), \alpha$ : 係数（砂質土 $\alpha=4$, 粘性土 $\alpha=8$ )

上記検討式の基本は, (1)バイブロハンマーの総起振力 がセルの動的摩擦抵抗を上回ること, (2)総振動重量がセ ルの動的先端抵抗を上回ること, (3)セルの振動振幅が必 要振幅 $(\fallingdotseq 0.003 \mathrm{~m})$ 以上であること，の 3 条件であり， 周面摩擦力を主体とした検討となっている.

一般に, 振動によって土の内部摩擦角・粘性抵抗力 · 間隙比などが影響を受け，その度合が粘性土よりも非粘 性土,特に砂に対して大であることはよく知られている. たとえば，D.D. Barkan は砂について，振動台を用い た実験で含水比や粒径を変えながら内部摩擦角の変化な どを調べており, 一例として振動加速度と振動時の内部 摩擦角の関係を次式および図一 5 で示している ${ }^{6)}$.

$\tan \phi=\left(\tan \phi_{s t}-\tan \phi_{\infty}\right) \exp (-b \eta)+\tan \phi_{\infty}$

ここに, $\tan \phi:$ 振動時の内部摩擦係数

$\tan \phi_{s t}:$ 振動がないときの内部摩擦係数

$\tan \phi_{\infty}$ : 振動時の内部摩擦係数の下限値 $\eta$ : 振動加速度 $(\mathrm{G})$

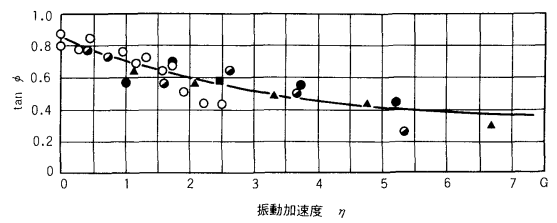

図一5 振動加速度と内部摩擦係数の関係 ${ }^{6}$ 
$b$ : 係数（乾燥した中砂の場合 $b=0.23 ）$ 振動時の周面摩擦低減率を $\mu=\tan \phi / \tan \phi_{s t}$ と考える と，式（4）は式（2）の第 2 式と同様の式となる.

また，谷本は砂質土に対して実施した実験例を集め, 振動加速度 $\eta$ 之内部摩擦係数比 $\tan \phi / \tan \phi_{s t}$ の関係を 整理し，それぞれの土に対し次のような一般式で表わさ れることを報告している7).

$\tan \phi / \tan \phi_{s t}=a-b \cdot \log \eta$

このほか, ソ連の文献では振動貫入時のバイブロハン マ一出力および杭の貫入速度から杭の極限支持力を求め る動的算定式が示されている ${ }^{8)}$.

（2）バイブロハンマーの出力式

鋼板セル打設に関する振動モデルは図一6に示す 3 種 類に区分される.この振動モデルを 1 質点・自由度 1 の 振動方程式で一般化すると式（6）のようになる.

$m \ddot{y}+c \dot{y}+k y=P \cdot \sin \omega t$

上式の解は以下のとおりである.

$$
y=\frac{P}{m} \cdot \frac{1}{\sqrt{\left(\omega^{2}-\lambda^{2}\right)^{2}+4 \gamma^{2} \omega^{2}}} \cdot \sin (\omega t+\phi) \cdot
$$

ただし， $\lambda^{2}=\lambda_{0}^{2}+C_{s} \cdot \lambda_{s}^{2}$

$$
\begin{aligned}
& \lambda_{0}^{2}=k_{0} / m, \quad \lambda_{s}^{2}=k_{s} / m \\
& \gamma=c /(2 m), \quad m=Q_{0} / g \\
& \psi=\tan ^{-1}\left\{2 \omega \gamma /\left(\omega^{2}-\lambda^{2}\right)\right\}
\end{aligned}
$$

ここに, $m$ : 振動系の質量 $\left(\mathrm{tf} \cdot \mathrm{s}^{2} / \mathrm{m}\right), c$ : 減衰係数 $(\mathrm{tf} \cdot \mathrm{s} / \mathrm{m}), \quad P$ : 起振力 $(\mathrm{tf}), \omega$ : 円振動数 $(\mathrm{rad} / \mathrm{s})$, $t:$ 時間 $(\mathrm{s}), y$ : 鉛直方向の変位 $(\mathrm{m}), \lambda_{0}, \lambda_{s}$ : ショッ クアブソーバーおよび地盤のばねによる固有振動数 $\left(\mathrm{s}^{-1}\right), k_{0}, k_{s}$ : 同ばね定数 $(\mathrm{tf} / \mathrm{m}), \gamma$ : 粘性抵抗係数 $\left(\mathrm{s}^{-1}\right), Q_{0}:$ 総振動重量 $(\mathrm{tf}), g:$ 重力加速度 $(=9.8$ $\left.\mathrm{m} / \mathrm{s}^{2}\right), C_{s}$ : 補正係数

ここで式 $(7)$ を用いて，図一6における(1)の状態す なわちアイドリング時の振幅ならびに振動加速度を求め てみる．アイドリング状態では地盤の粘性抵抗係数 $\gamma$ や地盤ばねの固有振動数 $\lambda_{s}$ は無視されるから $P=P_{0}$ と おいて式 $(7)$ より次のように示されるき11.

$$
a_{0}=\frac{g P_{0}}{\left(\omega_{0}^{2}-\lambda_{0}^{2}\right) Q_{0}}, \quad \eta_{0}=\frac{\omega_{0}^{2} P_{0}}{\left(\omega_{0}^{2}-\lambda_{0}^{2}\right) Q_{0}}
$$

ここに, $a_{0}$ :アイドリング時の振幅 $(\mathrm{m})$

$\eta_{0}$ :アイドリング時の振動加速度 $(G)$

注 1） セル打設時の地盤抵抗を $R$, バイブロハンマーの出力 増加に伴う地盤抵抗低減力を $R_{V}$ とし，七ルの貫入抵抗 が減衰力 $c \dot{y}$ に等しいと仮定すると, $c \dot{y}=R-R_{V}$ と表 わせる.この式と式 $(7)$ を用いて振幅 $a$, 振動加速度 $\eta$ を求めると, 次式が導かれる。

$a=g \sqrt{P^{2}-\left(R-R_{v}\right)^{2}} /\left\{\left(\omega^{2}-\lambda^{2}\right) Q_{0}\right\}, \quad \eta=a \omega^{2} / g$

上式はアイドリング時では $c=0$ より式（８）に一致する. 一般に軟らかい地盤において， $\eta$ は根入れの増加に比べ てほぼ一定の值である。これはバイブロハンマーの特性 によるもので， $R$ の増加に応じて限界出力以内では出力 が増加するよう挙動すると考えられる。

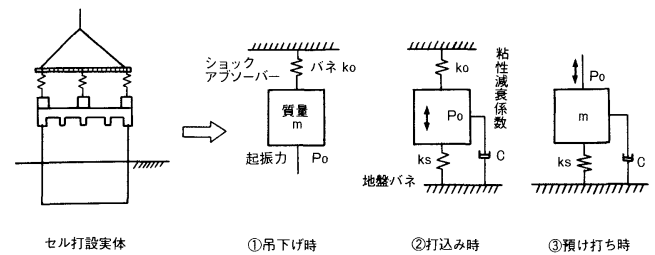

図一6振動モデル

$\omega_{0}$ :アイドリング時の円振動数 $(\mathrm{rad} / \mathrm{s})$

一般に振動打設時のバイブロハンマー出力 $W(\mathrm{~kW})$ は，アイドリング状態の出力 $W_{0}$ と根入れ増加に伴って 変化する出力増分 $\Delta W$ の和として表わされる.さらに アイドリング時の出力は, 総振動重量と平均振動速度の 積で, また打設中の出力増分は, 地盤抵抗 $R$ と平均振 動速度の積で表わされ，式（９）のようになる.

$$
\begin{aligned}
& W=W_{0}+\Delta W \\
& W_{0}=9.8 \cdot C_{0} \cdot Q_{0} \cdot a_{0} \cdot \omega_{0} / 2 \\
& \Delta W=9.8 \cdot R \cdot a \cdot \omega / 2 \\
& \text { ここに, } C_{0} \text { : バイブロハンマーの運転効率 }
\end{aligned}
$$

セル打設中の円振動数 $\omega$ および振動加速度 $\eta$ を, ア イドリング時の值 $\omega_{0}, \eta_{0}$ に対する変化率と考え,

$$
\omega / \omega_{0}=C_{\omega}, \quad \eta / \eta_{0}=C_{\eta}
$$

とすると，打設中およびアイドリング時の振幅 $a, a_{0}$ の 関係は，式（10）を用いて次式で表わされる.

$$
a / a_{0}=C_{n} / C_{\omega}^{2}
$$

いま振動貫入中のバイブロハンマー出力を使用台数 $n$ の平均值として $W, W_{0}, \Delta W$ を考え, 式 ( 8$)$ 一式 (11) より求めると次のように表わされる.

$$
\begin{aligned}
& W=W_{0}+\Delta W \\
& W_{0}=C_{0} \cdot \frac{9.8 g \omega_{0}}{2\left(\omega_{0}^{2}-\lambda_{0}^{2}\right)} \cdot \frac{P_{0}}{n} \\
& \Delta W=\frac{C_{n}}{C_{\omega}} \cdot \frac{9.8 g \omega_{0}}{2\left(\omega_{0}^{2}-\lambda_{0}^{2}\right)} \cdot \frac{P_{0}}{Q_{0}} \cdot \frac{1}{n} \cdot R
\end{aligned}
$$

上式よりバイブロハンマー出力 $W$ が，地盤の動的貫入 抵抗 $R$ と, 打設中の円振動数ならびに振動加速度の変 化率 $C_{\omega}, C_{\eta}$ に支配されることがわかる.

\section{（3）地盤の貫入抵抗}

セル打設時の地盤条件として $N$ 值を考え, 海底地盤 面 $(z=0 \mathrm{~m})$ の $N$ 值を $N_{0}$, 深さ $1 \mathrm{~m}$ ごとに $m$ の割合 で増加する地盤を想定し,

$$
N=m z+N_{0}
$$

とする. 次に周面摩擦，先端抵抗それぞれについて振動

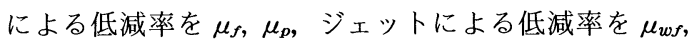
$\mu_{w p}$ とすると, セル打設時の地盤の貫入抵抗 $R$ は $R=$ $R_{f}+R_{p}$ より次式で表わされる.

$$
R=\mu_{w f} \cdot \mu_{f} \cdot R_{f}^{\prime}+\mu_{w p} \cdot \mu_{p} \cdot R_{p}^{\prime} \cdots
$$

ここに, $R_{f}, R_{p}$ : 打設時の周面摩擦, 先端抵抗 $(\mathrm{tf})$ 
$R_{f}^{\prime}, R_{p}^{\prime}$ : 静的周面摩擦，静的先端抵抗 $(\mathrm{tf})$ ここで $R_{f}^{\prime}$ はセルの内外接触面積 $A_{f}$ に働き， $R_{p}^{\prime}$ はセル 先端肉厚 $t_{p}$ の面積 $A_{p}$ に働くものとする. $R_{f}^{\prime}$ および $R_{p}^{\prime}$ を $N$ 值との関連でどう表わすかが問題となるが,ここ では静的支持力を便宜上， $R_{f}^{\prime}=1 / 5 N \cdot A_{f}$ および $R_{p}^{\prime}=$ $30 N \cdot A_{p}$ とした場合を考えるものとする.この場合， 砂質地盤の貫入抵抗は次式で表わされる。

$$
\begin{aligned}
R= & \mu_{w s} \mu_{f} \cdot 1 / 5 \cdot \pi D z\left(m z+2 \cdot N_{0}\right) \\
& +\mu_{w_{p}} \mu_{p} \cdot 30 \cdot \pi D t_{p}\left(m z+N_{0}\right)
\end{aligned}
$$

関西国際空港における平均的地盤条件 $N=2.5 z$, 七 儿諸元 $D=23 \mathrm{~m}, t_{p}=0.022 \mathrm{~m}$ の場合, 上式は

$$
R=\mu_{w f} \mu_{f} \cdot 36.1 z^{2}+\mu_{w p} \mu_{p} \cdot 119 z \cdot
$$

のように求められる.

\section{（4）振動による低減率}

振動による低減率については, 土の動的な強度・変形 特性に関する影響因子が多種多様であり, 低減率を一般 的な形で表現することは容易ではない. 式 (2) の第 2 式が現在用いられているが, 今後, Barkan や谷本によ る関係式 $(4)$ ，（5）などをふまえた研究ならびに実績 の積み重ねが必要と思われる.

\section{4. ウォータージェットによる低減効果の理論 的検討}

杭の振動貫入においてジェットを併用した事例は多い が，ジェットの効果やメカニズムについて定量的に研究 した文献はきわめて少ない，本章では，ジェットの低減 効果をセル先端部の切崩し現象によるものと, 七ル周面 部の洗掘効果によるものに分け，前者は鈶直ジェットに よる海底土砂の切崩し実験の成果 ${ }^{9}$, 後者はフィルダム の洗掘に関する限界流速理論 ${ }^{10)} も と に$ 考察・検討を加 える，こうした低減率の考え方を図一7に示す。

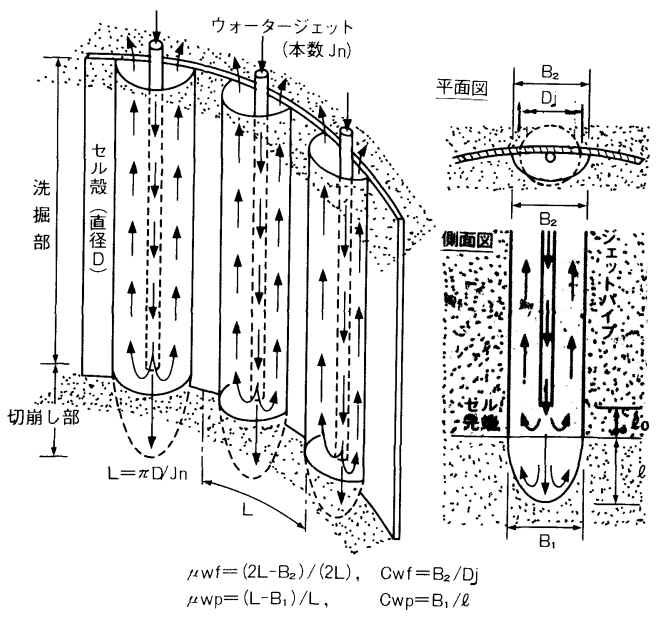

図一7 ジェットによる低減率概念図

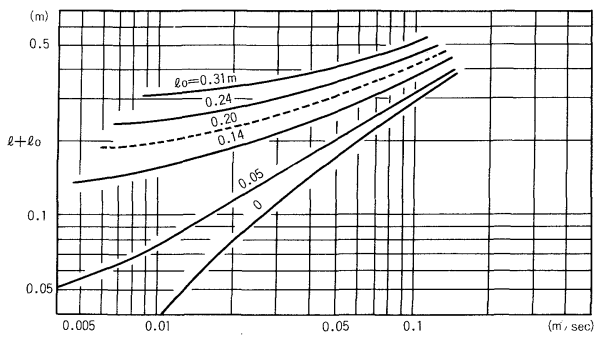

図一8 ジェットによる砂の切崩し実験結果 ${ }^{9)}$

\section{（1）切崩し実験式による先端抵抗低減率}

図一8中の実線は文献 9）による砂の三次元切崩し実 験結果を示す。また破線は実験結果の各パラメーターを もとに今回のセル打設におけるジェットノズル位置 20 $\mathrm{cm}$ のケースを内挿したものである. 図一8より実験式 （16）を求めノズル位置 $20 \mathrm{~cm}$ の場合の近似式を求め てみる.

$$
l+l_{0}=a \nu^{1 / 3}\left(b_{j} V_{j}\right)^{2 / 3} /\left(g d_{m}\right)^{1 / 2}-b
$$

ここに，l:セル先端からのジェット切崩し深さ $(\mathrm{m})$

$l_{0}:$ セル先端上方のノズル位置 $(=0.2 \mathrm{~m})$

$\nu$ : 水の動粘性係数 $\left(=10^{-6} \mathrm{~m}^{2} / \mathrm{s}\right)$

$b_{j}:$ ジェットノズル径 $(\mathrm{m})$

$V_{j}:$ :゙ェットの噴出速度 $(\mathrm{m} / \mathrm{s})$

$d_{m}:$ 砂の平均粒径 $(\mathrm{m})$

$g:$ 重力加速度 $\left(=9.8 \mathrm{~m} / \mathrm{s}^{2}\right)$

$\therefore \quad l=11.36 \cdot \nu^{1 / 3}\left(b_{j} V_{j}\right)^{2 / 3} /\left(g d_{m}\right)^{1 / 2}-0.07 \cdots$

ジェットによる先端抵抗低減率 $\mu_{w p}$ を次式で定義する.

$\mu_{w p}=1-J_{n} \cdot B_{1} /(\pi D)=1-C_{w p} J_{n} \cdot l /(\pi D)$.

ここに, $J_{n}:$ ジェットノズル数

$B_{1}$ : ノズル 1 本当たりの切崩し幅 $(\mathrm{m})$

$C_{w p}:$ ジェットによる切崩し深さに対するセル先 端部の切崩し幅の比(切削形状係数とよぶ) さらにジェットノズル 1 本当たりの噴出流量 $Q_{j}(l / \mathrm{min})$

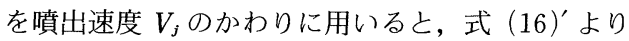

$$
\mu_{w p}=1-C_{w p}\left\{2.78 \times 10^{-5} \cdot \frac{J_{n} Q_{j}^{2 / 3}}{\pi D d_{m}^{1 / 3} b_{j}^{2 / 3}}-0.07 J_{n} /(\pi D)\right\}
$$

となり, 式 (18) に今回の施工諸元 $\left(D=23 \mathrm{~m}, J_{n}=48\right.$ 本, $\left.d_{m}=0.48 \times 10^{-3} \mathrm{~m}, \quad b_{j}=4.5 \times 10^{-3} \mathrm{~m}\right)$ を代入すると下 式が得られる.

$$
\mu_{w p} \doteqdot 1-0.0309 \cdot C_{w p} \cdot Q_{j}^{2 / 3}
$$

\section{（2）洗掘理論式による周面摩擦低減率}

文献 10)によるとさまざまな粒径の粒子が動く場合 の限界流速 $V_{c}$ は式(19)および図 9 で与えられている.

$$
V_{c}=\left\{2 / 3 \cdot\left(G_{s}-1\right) \cdot d_{m} \cdot g\right\}^{1 / 2}
$$

ここに, $G_{s}:$ 土粒子比重

ジェット水流により形成される洗掘形状を直径 $D_{j}$ の円 


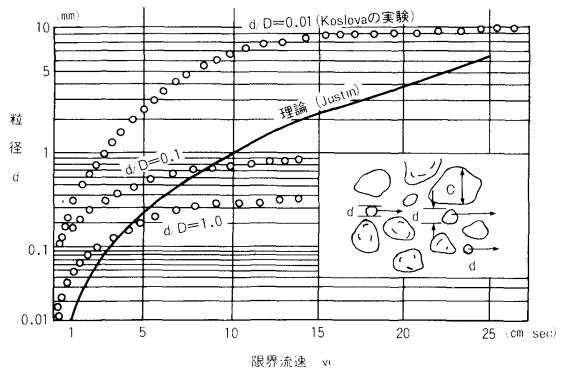

図一-9 粒径に応じた限界流速 ${ }^{10)}$

形亡し, 限界流速 $V_{c}$ をノズル 1 本当たりの噴出水量 $Q_{j}(l / \mathrm{min})$ で表わすと,

$D_{j}=0.0051\left\{\left(G_{s}-1\right) d_{m} \cdot g\right\}^{-1 / 4} Q_{j}^{1 / 2}$

となる.ここで, ジェットによる周面摩擦低減率 $\mu_{w f}$ を 式（21）で定義すると式（22）が得られる.

$\mu_{w f}=1-J_{n} \cdot B_{2} /(2 \pi D)=1-C_{w f} J_{n} \cdot D_{j} /(2 \pi D) \cdots(21)$

ここに, $B_{2}$ : ジェット水流 1 本当たりの洗掘幅 $(\mathrm{m})$

$C_{w f}$ : ジェット水流によるセル洗掘幅と同面積の 円形洗掘直径 $D_{j}$ の比（洗掘形状係数亡よ ふi)

$$
\therefore \quad \mu_{w f}=1-C_{w f} \cdot \frac{0.0025 J_{n} Q_{j}^{1 / 2}}{\pi D\left\{\left(G_{s}-1\right) d_{m} g\right\}^{1 / 4}}
$$

今回の施工諸元および $G_{s}=2.65, d_{m}=0.48 \times 10^{-3} \mathrm{~m}$ を 式（22）に代入すると下式が得られる.

$\mu_{w f}=1-0.0057 \cdot C_{w f} \cdot Q_{j}^{1 / 2}$

（3）アイドリング時のバイブロハンマー出カ

アイドリング状態のバイブロハンマー出力 $W_{0}$ は, 式

（12）の第 2 式より求められる。ジェットを併用する場 合水中での噴射反力などにより一部の出力が低減すると 考えられるが，この場合のアイドリング出力 $W_{w 0}$ を, ジェットの影響を受け出力変動する項と, 影響を受けな い出力一定の項の和として次式で表わす.

$W_{w 0}=\left\{\beta \cdot \mu_{w}+(1-\beta)\right\} W_{0} \cdot$

ここに， $\beta$ : ジェットの影響を受ける出力割合（ジェッ

卜影響率とよぶ)

$\mu_{w}:$ ジェットによるアイドリング出力低減率

今回の解析においては, ジェット流量のみ $l / \mathrm{min}$ 単 位を便宜上用い, 出力は消費電力 $\mathrm{kW}$ 単位, その他は $\mathrm{tf}, \mathrm{m}, \mathrm{s}$ 単位を用いた。

\section{5. 鋼板セル打設記録の解析}

本章では 3., 4. の理論的検討で得られた諸係数やそ の特性を関西国際空港の現場での打設記録より検討解析 し，その結果をふまえ算定式と実測值の対比を行った。

関西国際空港で打設した鋼板セル全 69 函のうち, バ イブロハンマーのみで打設したのは 3 函（セルNo.69 67）であり，ジェットを併用しかつノズル位置がセル先
端より $20 \mathrm{~cm}$ 上方のものが 59 函であった。そのため打 設記録の解析は上記 62 函を対象とした。記録項目は, バイブロハンマー出力 $W$, 振動数 $\omega$, 打設深さ $z$, 貫 入速度 $v$, ジェット圧力 $p$ および流量 $Q$, 吊り荷重そ してセルの傾斜（2 方向）の8 項目であった.

\section{(1) アイドリング出カ}

打設記録よりジェットを併用しないセル 3 函のアイド リング出力は， $W_{0}=53 \mathrm{~kW}$ であった. これから当現場 におけるバイブロハンマーの運転効率 $C_{0}$ を式 (12) お よび表一2 の施工諸元より求めると, 次の值となる.

$C_{0}=0.81$

一方，ジェット併用時のアイドリング出力 $W_{w_{0}}$ と ジェット総流量 $Q$ の関係は図一10で示される。これら データの双曲線近似を行うと，

$W_{w 0}=15 \times 1750 /(Q+1750)+38$

となり，当現場におけるジェット影響率 $\beta$ およびアイ ドリング出力低減率 $\mu_{w}$ は以下のように求められる.

$$
\left.\begin{array}{l}
\beta=0.283 \\
\mu_{w}=1750 /(Q+1750) \text { または } 36.5 /\left(Q_{j}+36.5\right)
\end{array}\right\}
$$

\section{（2）周面摩擦と先端抵抗}

セル打設中に傾斜修正のためにいったん引抜き再貫入 させたデータから, 引抜き時と直前の貫入時のジェット 流量が同じものを抽出して, 図一11のように[貫入時 出力ーアイドリング出力] が周面摩擦と先端抵抗の和に 相当，同じ深さにおける [貫入時出力一引抜き時出力] が先端抵抗に相当するものと考え解析を実施した.

図一12 はこの解析結果からバイブロハンマー出力 $W$ 中に占めるアイドリング出力 $W_{0}$, 周面摩擦相当出力 $W_{f}$, 先端抵抗出力 $W_{p}$ の割合すなわち $W_{0} / W, W_{f} / W$, $W_{\rho} / W$ を打設深さについて調べたものである．実線お よび破線はジェット併用時の上記割合の分布および平均 值をそれぞれ示す。

比較のために打設深さ $7 \mathrm{~m}$ 付近の出力内訳 $\left(W_{0}: W_{f}\right.$ ： $\left.W_{p}\right)$ をみると, ジェットを併用しない場合 $25: 60$ :

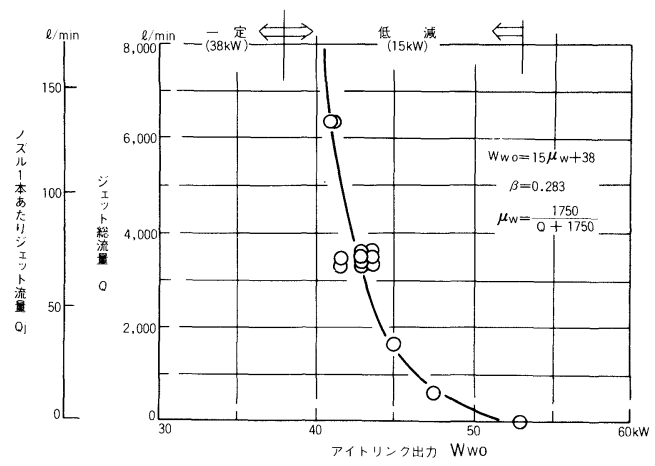

図一10 ジェット流量とアイドリング出カの関係 


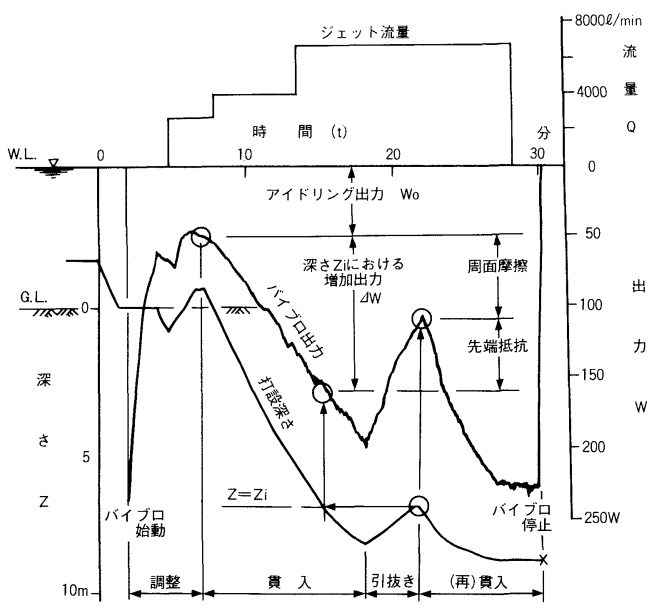

図一11 セル打設記録解析例

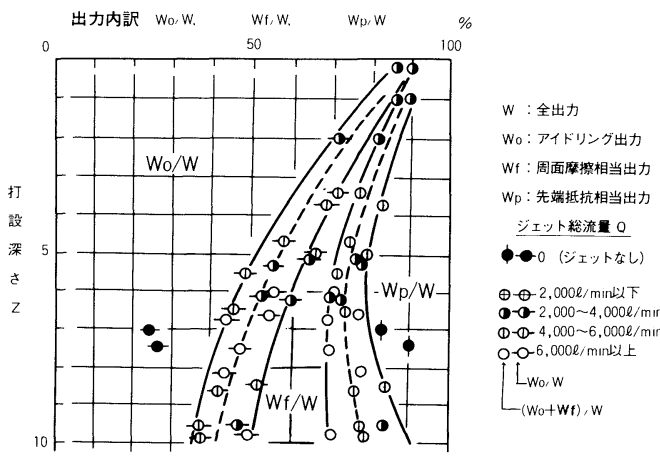

図一12 ジェット併用時の出力内訳

15 程度であったのに対し, 併用の場合は $50: 25: 25$ 程 度であり，周面摩擦が先端抵抗とほぼ同じ程度にまで低 減している。ジェット併用によって周面摩擦がより大き く低減していることがわかる.

\section{（３） 円振動数, 振動加速度の変化}

セル体や杭体の貫入抵抗の増大に伴いバイブロハン マーの振動数が減少することは経験的に知られている が，今回の記録よりジェット併用のないセル 3 函につい て, 式 (15) 之同様の考え方で求めた静的支持力 $R^{\prime}\left(=R_{f}^{\prime}\right.$ $\left.+R_{p}^{\prime}\right)$ と円振動数 $\omega$ との関係を求めたものを図一13に 示し, その分布範囲と平均值を併示した。 この場合の地 盤条件は平均 $N$ 值 $=2.5 z$ とし, アイドリング時円振動 数は $\omega_{0}=88.5 \mathrm{rad} / \mathrm{s}$ とした. 図一13 より円振動数変化 率 $C_{\omega}$ を求めると下式のようになり, 円振動数はアイド リング時より最大 $5 \%$ 程度の減少であった.

$$
\omega=88.5-0.0016 \cdot R^{\prime}
$$$$
\therefore \quad C_{\omega}=1-1.8 \times 10^{-5} \cdot R^{\prime}
$$

ただし, $R^{\prime}=1 / 5 \cdot \pi D z\left(m z+2 \cdot N_{0}\right)+30 \cdot \pi D t_{p}\left(m z+N_{0}\right)$ なお, 振動加速度は今回実測されなかったが他現場(東

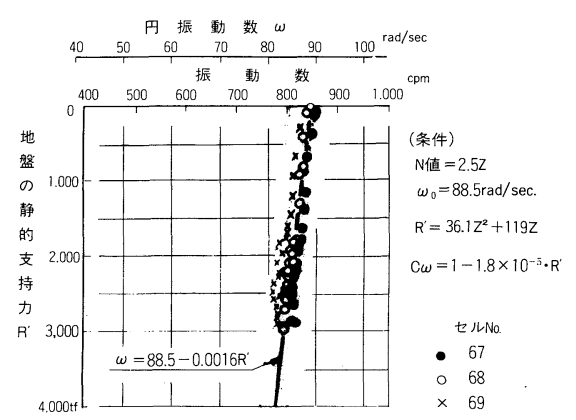

図一13 振動数と静的貫入抵抗の関係

京湾 10 号地・砂質地盤）で得られた実測值では下式の ように多少のばらつきはあるが，ほぼ一定の值と考えて よいと思われる ${ }^{11}$. 今回の解析では $C_{n}=1.0$ とした.

$$
C_{n}=0.9 \sim 1.1\left(\text { 平均 } C_{\eta} \doteqdot 1.0\right) \text {. }
$$

\section{（4）振動による低隇率}

前節と同様ジェット併用のないセル 3 函について，バ イブロハンマー出力式 (12) に式 (26), (27) の值およ び今回の施工諸元, 地盤条件（平均 $N=2.5 z$ ）を代入 して振動による低減率 $\mu_{f}, \mu_{p}$ を求める.

$$
\Delta W=\frac{1.0}{1-1.8 \times 10^{-5} R^{\prime}} \cdot \frac{9.8 \times 9.8 \times 88.5}{2 \times\left(88.5^{2}-33.6\right)} \cdot \frac{960}{394.3} \cdot \frac{1}{8} \cdot R
$$

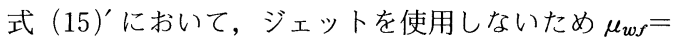
1. $0, \mu_{w p}=1.0$ とすると,

$$
\begin{aligned}
& R=\mu_{f} \cdot 36.1 z^{2}+\mu_{p} \cdot 119 z \\
& R^{\prime}=36.1 z^{2}+119 z
\end{aligned}
$$

となる. 一方, セル 3 函の施工記録より深さ $z=7.25 \mathrm{~m}$ における周面摩擦相当出力 $W_{f}=121 \mathrm{~kW}$, 先端抵抗相当 出力 $W_{p}=31 \mathrm{~kW}$ の平均実測值を上記 3 式にあてはめて 振動による低減率 $\mu_{f}$ および $\mu_{p}$ を求める.

振動による周面摩擦低減率 $\mu_{s}=0.363$

振動による先端抵抗低減率 $\mu_{p}=0.204$

なお式（2）より得られる低減率は $\mu=0.196$ であった。

以上の記録解析結果より, ジェット併用のない場合の バイブロハンマー出力 $W_{v}$ は今回の施工諸元および地盤 条件の場合, 式 (12), (15) より次式のように表わされ る.

$$
\begin{aligned}
W_{v}=53+\frac{0.166}{1-1.8 \times 10^{-5} R^{\prime}} \cdot R \cdots \\
\text { ただし, } R=5.24 \mathrm{mz}^{2}+9.72 \mathrm{mz} \\
R^{\prime}=14.4 \mathrm{mz}^{2}+47.7 \mathrm{mz}
\end{aligned}
$$

（５）ウォータージェットによる低減率

a) ジェットによる出力低減特性

ジェット併用時の出力低減特性をみるために, ジェッ トを併用した 59 函の実測出力分布より深さごとに中央 值 $W_{M}$ を求め, 式 (30) による出力 $W_{V}$ との比 $W_{M} / W_{V}$ とジェット流量 $Q$ との関係を調べた。図一14 に示すよ 
うに, 出力比 $W_{M} / W_{V}$ はジェット流量 $Q$ の増大に従い減 少していくが，その減少度合は打設深さが大きくなるほ ど顕著であることがわかる．この傾向は次式のような近 似式で与えられるが, 右辺は式 (25) 第 2 式に一致する4).

$$
\left(W_{M}-38\right) /\left(W_{V}-38\right)=1750 /(Q+1750) \cdots
$$

b) ジェットによる低減率の分布

ジェットを併用したセル打設記録のうち打設途中に引 き抜いた全 23 例について, 引抜き地点の地盤 $N$ 值= $m z$ を逆算し, $m, z$ に対応する出力実測值 $W$ と, 式 （30）より求めたジェットを併用しない場合の出力計算 值 $W_{v}$ との比を周面摩擦 $\mu_{w s}$, 先端抵抗 $\mu_{w p}$ それぞれに ついて求めた。その結果は図一15に示すとおりである.

ジェット流量 $Q_{j} \geqq 80 \mathrm{l} / \mathrm{min}(Q \geqq 3840 \mathrm{l} / \mathrm{min})$ の場合, 図一15中に実線でその分布範囲が示されている，周面 摩擦低減率は $\mu_{w r}=0.1 \sim 0.2$, 先端抵抗低減率は $\mu_{w p}=$ $0.4 \sim 0.8$ であり, 周面摩擦の低減効果の方が大である. 先端抵抗低减率の值についてはジェットノズルの取付け 位置 $20 \mathrm{~cm}$ が影響していると思われる.

c) 洗掘形状係数

前記の方法で得られたジェットによる周面摩擦低減率 $\mu_{w s}$ とジェット流量 $Q_{j}$ を用いて, 式 $(22)$ より洗掘形 状係数 $C_{w s}$ が求められる. このようにして算出された 洗掘形状係数 $C_{w f}$ と地盤の静的周面摩擦 $R_{f}^{\prime}(=14.4$ $\left.m z^{2}\right)$ との関係を図一16に示す.

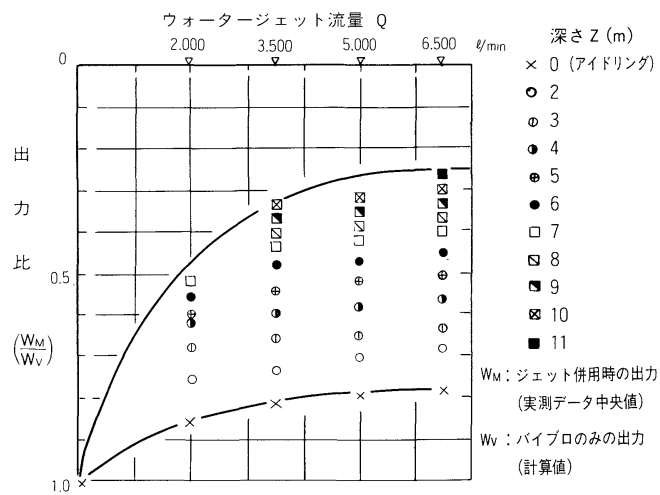

図一14 ジェット併用有無による出力比
洗掘形状係数 $C_{w f}$ は前述したようにジェットノズル 1 本ごとにジェット水流によってセルに沿って形成され る洗掘断面の偏平の度合を示すものである. 洗掘形状係 数 $C_{w s}$ は, 図一16 中の実線で示す範囲に分布しており, ジェット流量にかかわらず, 打設深さが増大し静的周面 摩擦 $R_{f}^{\prime}$ が増加するに従い減少の傾向を示す. その傾向 は図一16より次式のように表わされる.

$$
C_{w f} \geqq 15-4.0 \times 10^{-4} \cdot R_{f}^{\prime}
$$

d) 切削形状係数

同様にしてジェットによる先端抵抗低減率 $\mu_{w p}$ と ジェットノズル 1 本当たりのジェット流量 $Q_{j}$ を用い式 $(18)^{\prime}$ より切削形状係数 $C_{w p}$ が求められる. 図一17 は 切削形状係数 $C_{w p}$ と地盤の静的先端抵抗 $R_{p}^{\prime}(=47.7$ $m z)$ の関係を示したものである. 切削形状係数は, 洗 掘形状係数に比べてばらつきが大であるが，その中で ジェット流量 $Q_{j} \geqq 80 \mathrm{l} / \mathrm{min}$ についてみると, 図一17 の 実線で示されるように切削形状係数は打設深さが増大 し, 静的先端抵抗の増加に伴い急激に減少していく．そ の傾向は図一17より次式のように表わされる.

$$
C_{w p} \geqq 1.2-7.0 \times 10^{-4} \cdot R_{p}^{\prime}
$$

\section{（6）バイブロハンマー出力式}

ジェット併用時のバイブロハンマー出力は実験式的に は式（31）を用いて求められるが，ここではより一般的 なバイブロハンマー出力算定式を示し，さらに今回の施 工諸元ならびに地盤条件の場合の出力式を，これまでの 解析結果をベースに求めてみる。

バイブロハンマー出力算定式は, 式 (12), (14),

を総合して次式で表わされる.

$$
\begin{aligned}
W= & \left\{\beta \mu_{w}+(1-\beta)\right\} C_{0} \cdot \frac{9.8 g \omega_{0}}{2\left(\omega_{0}^{2}-\lambda_{0}^{2}\right)} \cdot \frac{P_{0}}{n}+\frac{C_{\eta}}{C_{\omega}} \cdot \frac{9.8 g \omega_{0}}{2\left(\omega_{0}^{2}-\lambda_{0}^{2}\right)} \\
& \cdot \frac{P_{0}}{Q_{0}} \cdot \frac{1}{n}\left(\mu_{f} \mu_{w f} R_{f}^{\prime}+\mu_{p} \mu_{w p} R_{p}^{\prime}\right) \cdots \cdots \cdots \cdots \cdots \cdots(34)
\end{aligned}
$$

ただし， $R_{f}^{\prime}=1 / 5 \cdot \pi D z\left(m z+2 \cdot N_{0}\right)$

$$
R_{p}^{\prime}=30 \cdot \pi D t_{p}\left(m z+N_{0}\right)
$$

式（34）に当現場の施工諸元，地盤条件 $N$ 値 $=m z$ お よび今回の解析結果を適用すると以下のように示され る.

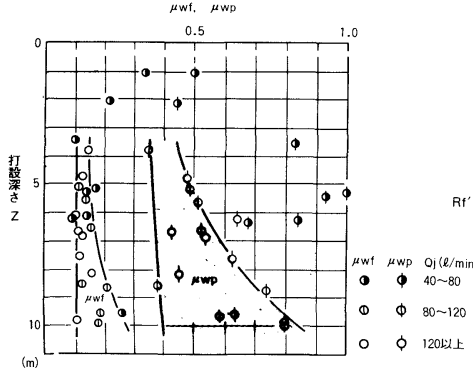

図一15 ジェットによる低減率の分布

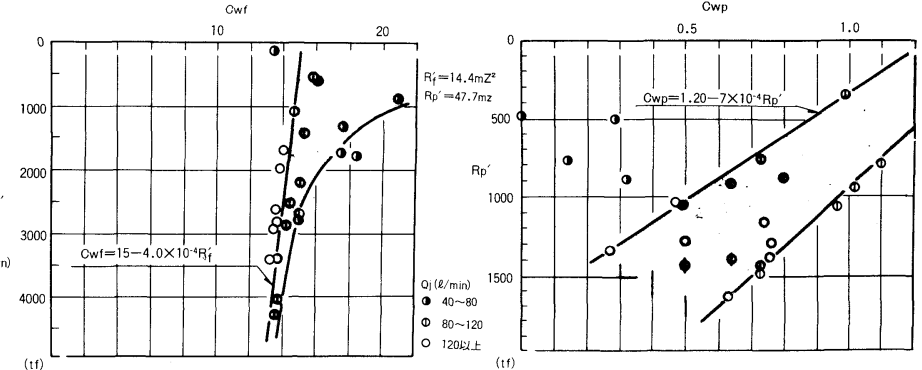

図一16 洗掘形状係数（周面摩擦）
図一17 切削形状係数（先端抵抗） 


$$
\begin{aligned}
W \leqq & \left(38+\frac{547.5}{Q_{j}+36.5}\right)+\frac{0.166}{1-1.8 \times 10^{-5}\left(R_{f}^{\prime}+R_{p}^{\prime}\right)} \\
& \cdot\left[\left\{1-0.0057\left(15-4.0 \times 10^{-4} R_{f}^{\prime}\right) Q_{j}^{1 / 2}\right\} \mu_{f} R_{f}^{\prime}\right. \\
& \left.+\left\{1-0.0309\left(1.2-7.0 \times 10^{-4} R_{p}^{\prime}\right) Q_{j}^{2 / 3}\right\} \mu_{p} R_{p}^{\prime}\right]
\end{aligned}
$$

ただし $, \mu_{f}=0.363, \quad \mu_{p}=0.204$

$$
R_{f}^{\prime}=14.4 \mathrm{mz}^{2}, \quad R_{p}^{\prime}=47.7 \mathrm{mz}
$$

当然のことながらジェットを併用しない場合，すなわち $Q_{j}=0$ の場合, 式 $(34)^{\prime}$ は式 $(30)$ に一致する.

\section{（7）バイブロハンマー出力式と実測值との対比}

図一18 はジェット併用のないセル 3 函について，バ イブロハンマー出力式 (30) と実測值との対比である. 実測值は平均地盤 $N$ 値 $=2.5 z$ を中に $2.0 z \sim 3.0 z$ の 出力計算値の範囲内で分布しており, 比較的良い相関性 を示している. 図一18には参考のために $N$ 值 $=2.0 z$ の場合のバイブロハンマー出力内訳すなわちアイドリン グ出力 $W_{0}$, 周面摩擦相当出力 $W_{f}$ および先端抵抗相当 出力 $W_{\rho}$ の計算結果を併示した.

また図一19 はジェット併用のセル 59 函について，バ イブロハンマー出力式 $(34)^{\prime}$ を用い, 平均地盤 $N$ 值 $=$ $2.5 z$ としたときのバイブロハンマー出力上限值と実測 值との対比である. 実测值は, 地盤 $N$ 值の分布 $(N$ 値 $=1 \cdot z \sim 5 \cdot z)$ に起因すると考えられるばらつきは認め られるが，図一18 と同様良い相関性を示している.

今回用いたバイブロハンマーの定格出力は $150 \mathrm{~kW}$ で あるが，実測最大出力は $230 \mathrm{~kW}$ であり，バイブロハン マ一の限界出力は定格出力の 1.5 倍程度と考えられる.

\section{（8）記録解析結果の要約}

(1)〜（７）の結果を要約すると以下のようになる.

(1) 当現場におけるバイブロハンマー 8 台の運転効率 は $C_{0}=0.81$ であった. また円振動数は打設深さの増大 に従い減少するが, 当現場ではアイドリング時より最大

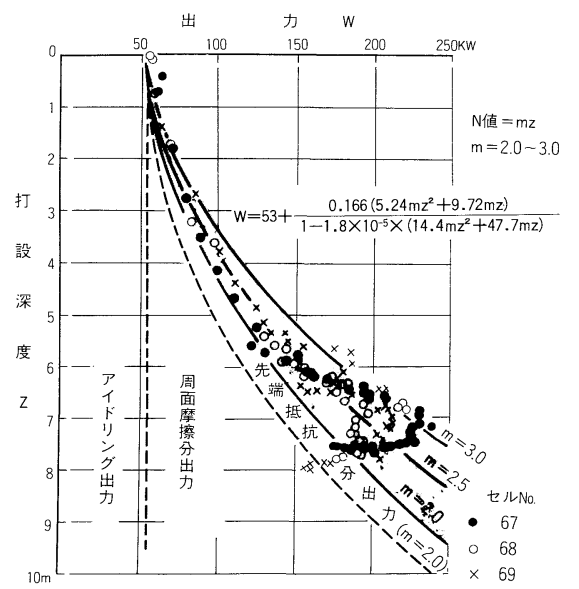

図一18 バイブロハンマー出力結果と出力式の対比
$5 \%$ 減少した.

(2) バイブロハンマー出力はジェット併用のない場合 で最大出力 $230 \mathrm{~kW}$ を記録した. 限界出力は定格出力 $150 \mathrm{~kW}$ の約 1.5 倍亡考えられる.

(3) バイブロハンマーの出力内訳（アイドリング出力 : 周面摩擦相当出力 : 先端抵抗相当出力 ) をジェットを 併用しない場合で出力内訳の得られた唯一のデータであ る打設深さ $7 \mathrm{~m}$ 付近で比較すると, 併用しない場合 25 ：60：15 程度に対し，併用の場合同じ深さでは $50 ： 25$ ：25 程度であり，ジェット併用により周面摩擦の低減 度合が大である。

(4) ジェット併用時のバイブロハンマー出力は, アイ ドリング出力の一部および増加出力が低減するが，併用 しない場合の出力に対し，たとえば打設深さ $7 \mathrm{~m}$ 付近 の場合, ジェット総流量 $2000 \mathrm{l} / \mathrm{min}$ で $50 \%$ 程度, $4000 \mathrm{l} / \mathrm{min}$ 以上では $40 \%$ 程度の值である。また深さ の増大に伴い, 低減の度合も大きくなる.

(5) 振動およびジェットによる低減率を上記と同じく 打設深さ $7 \mathrm{~m}$ 付近でみると：

1）振動による低減率は周面摩擦低減率 $\mu_{f}=0.363$, 先端抵抗低減率 $\mu_{p}=0.204$ であった。

2）ジェットによる低減率はジェットノズル 1 本当た り流量 $80 \mathrm{l} / \mathrm{min}$ (総流量約 $4000 \mathrm{l} / \mathrm{min}$ ) 以上の場合, 周面摩擦低減率 $\mu_{w f}=0.1 \sim 0.2$, 先端抵抗低減率 $\mu_{w p}=$ $0.4 \sim 0.6$ 程度であったが, 低減率算定式で用いた洗掘 形状係数は $C_{w f}=14 \sim 15$, 切削形状係数は $C_{w p}=0.6$ 1.0 であった.

(6) バイブロハンマー出力式は, ジェットを併用しな い場合において改良地盤平均 $N$ 値 $=2.5 z$ を中心に出力 実測值と良い相関性を示した. またジェット併用の場合, 上記出力式と現場で得られた低減率算定式との組合せに より出力実測值と良い相関がみられた.

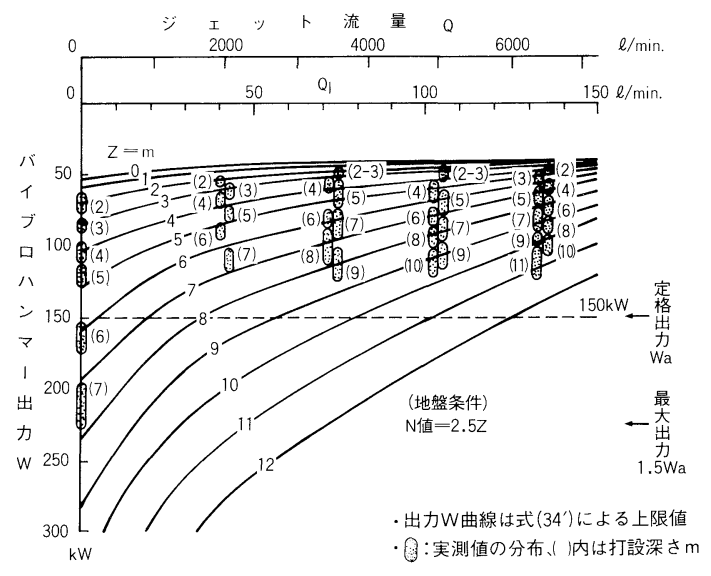

図一19 セル打設時の出力とジェット流量の関係 
(7) バイブロハンマー出力式を用いて，根入れ式鋼板 セル工法にわける打設能力の検討やジェット併用の必要 性さらに必要機械諸元を決定することが可能であり，ま た一般の振動杭打ち工法などにも応用できると思われ る.

\section{6. ジェット併用時の地盤への影響}

ジェットによるセル打設地盤の乱れの有無を調べるた めに，ジェット併用の打設セル（No.66）に対しセル款 内側 5 か所でセル中詰後に標準貫入試験を実施した。 セ ル打設前の地盤 $N$ 值に中詰土の荷重を考慮した推定換 算 $N$ 值と，上記標準貫入試験結果との対比を行ったが, ジェット併用による地盤の乱れや強度低下はあまりみら れず，むしろ $N$ 值の増大傾向が認められた

これは，セルが所定の打設深さに到達する直前に， ジェットを停止し，数分間バイブロハンマーのみによる 打設によりセルの打止め管理を実施したことにより，セ ル殼周辺地盤の締固めに寄与したと考えられる.

\section{7. ま と}

関西国際空港の空港島で採用された根入れ式鋼板セル 護岸工事のセル打設において採取された施工記録をもと に, バイブロハンマーによる振動貫入特性やジェット併 用による低減効果など施工性に重点をおいた研究を実施 し，実測結果を主体に新しく導いた関係式について検討 した．本論文の内容について以下にまとめる.

（1）セル打設時のバイブロハンマー出力は, 施工装 置諸元, 地盤の動的貫入抵抗, 施工中の振動数変化率お よび振動加速度の変化率より構成される出力式で求めら れ，実測值と良く一致した。地盤の動的貫入抵抗は $N$ 值を用いた地盤の支持力公式の周面摩擦，先端抵抗それ ぞれに振動による低減率およびジェットによる低減率を 乗じて求められる.

（2）このうちジェットによる低減率に関しては，さ らに低減率の一般化を考え, 七ル周面地盤の洗掘効果, セル先端地盤の切削効果を考慮した算定式を導き，その 中で用いられている係数を施工記録より求めた.

（３）新しく提案したバイブロハンマー出力式および ジェットによる低減率算定式は, 出力実測値と良い相関 がみられた。この結果根入れ式鋼板セル工法に限らず一 般の振動杭打ち工法などの打設能力の検討や施工機械の 選定に有効であると思われる.

（4）ジェット使用によるセル打設地盤の乱れ等につ いてはセル打設終了直前にジェットを停止し，バイブロ
ハンマーのみによる振動締固めを行うことにより対処す ることができた．

なお，本論文では関西国際空港における施工記録を用 いて出力算定式に対する解析を実施したが，今後さらに 他現場のデータにより出力算定式の検証を重衫る必要が ある．また，地盤（粘性土を含む）の振動による低減率 の定量的取扱いやジェット併用時のアイドリング特性な ぞについてもさらに研究を進める必要がある.

今後, 本論文の成果を応用発展させることにより, 振 動杭打ち工法などにおける杭体やセル体打設時の地盤強 度の推定に利用できる可能性を有している.

謝辞：本論文とりまとめに際し，関西国際空港 （株）建設事務所ならびに東亜・不動・清水・国土総合 建設工事共同企業体の諸氏に協力を賜った。また工事遂 行にあたっては関西国際空港（株）の小野文雄・元工事 長に尽力いただいた。ここに記して謝意を表します。

1）仮設鋼矢板施工ハンドブック，(社）日本建設機械化協会, p. 185, 1972.

2）前田 進・高井俊郎・福手 勤：サンドコンパクション パイルの大規模施工に伴う隆起地盤の形状と物性, 土木 学会論文集, 第 403 号 /VI-10, pp. 55 63，1989.3.

3）高井俊郎・今野建太郎・中村正邦・田村吉輝・多田邦夫 : サンドコンパクションパイル工法による地盤改良一関 西国際空港鋼板セル護岸および直立消波ケーソン護岸一, 昭和 63 年度施工技術報告会, 土木学会関西支部ほか。

4）高井俊郎 - 小野文雄 - 今野建太郎 - 中村正邦：関西国際 空港における根入れ式鋼板セル護岸の施工について, 第 13 回海洋開発シンポジウム, 土木学会, 1988.

5）根入れ式鋼板セル工法 施工・積算マニュアル，根入れ式 鋼板セル協会, pp. 40４6, 1984.8.

6) Barkan, D. D. : Dynamics of Bases and Foundations, McGraw-Hill, pp. 55〜75, 1960.

7）谷本喜一・柴田 徹：土の動的性質, 基礎工学ハンドブッ ク, 朝倉書店, 1965.

8）忠平健一：ソ連式振動杭打ち工法, 新しい基礎工法, 増 補版, 近代図書, pp. 78 91, 1969.2.

9）松田任・岩田尚生：ジェット掘削に関する研究（その 1) 鉛直ジェットによる海底土砂の切崩しについて, 港湾 技術研究所報告, Vol. 3, No. 5, 運輸省港湾技術研究所, 1964.11.

10）土質工学ハンドブック,第 27 章 フィルダム, 土質工学会, 1983. 7.

11）荻野秀雄・高瀬幸紀・梶岡保夫：根入れ式鋼板セル施工 実験, 土木学会第 35 回年次学術講演会講演概要集, 第 3 部, pp. 404 405, 1980.

(1989.6.19・受付) 